\title{
What are urban mangroves? ${ }^{1}$
}

\author{
Gabriela Reyes, Ashley Smyth, and Laura Reynolds²
}

\section{Overview}

In Florida, $80 \%$ of the residents live within 10 miles of the coast. As a result, coastal habitats, like mangroves, have been significantly altered by human activities. Urban mangroves are mangroves located in cities and residential areas. While urban mangroves may be highly impacted by humans, they continue to provide important ecosystem services, or benefits to society. In fact, due to their location, more people may benefit from these urban mangroves than from pristine mangroves, which are often located in protected areas. The following document describes the role of mangroves in urban areas. This document is intended for coastal residents, coastal resource managers, and urban planners who are interested in learning about mangroves and their importance in cities.

\section{What are mangroves?}

Mangroves are salt-tolerant wetland species that can form small patches or large forests and are found along tropical and subtropical coastlines. Florida has three native mangrove species: Rhizophora mangle (red mangrove), Avicennia germinans (black mangrove), and Laguncularia racemosa (white mangrove) (Figure 1). All three species have specialized roots for survival under waterlogged conditions, e.g., prop roots and pneumatophores. Red mangroves are characterized by their prop root systems and the red coloration of their bark when wet (see "Rhizophora Mangle, Red Mangrove"). Black mangroves are characterized by their dark, almost black bark and high concentration of pneumatophores (see "Avicennia Germinans, Black Mangrove"). White mangroves have some pneumatophores, but fewer than black mangroves, and can also be identified by their light-colored bark (see "Laguncularia racemosa, White Mangrove").
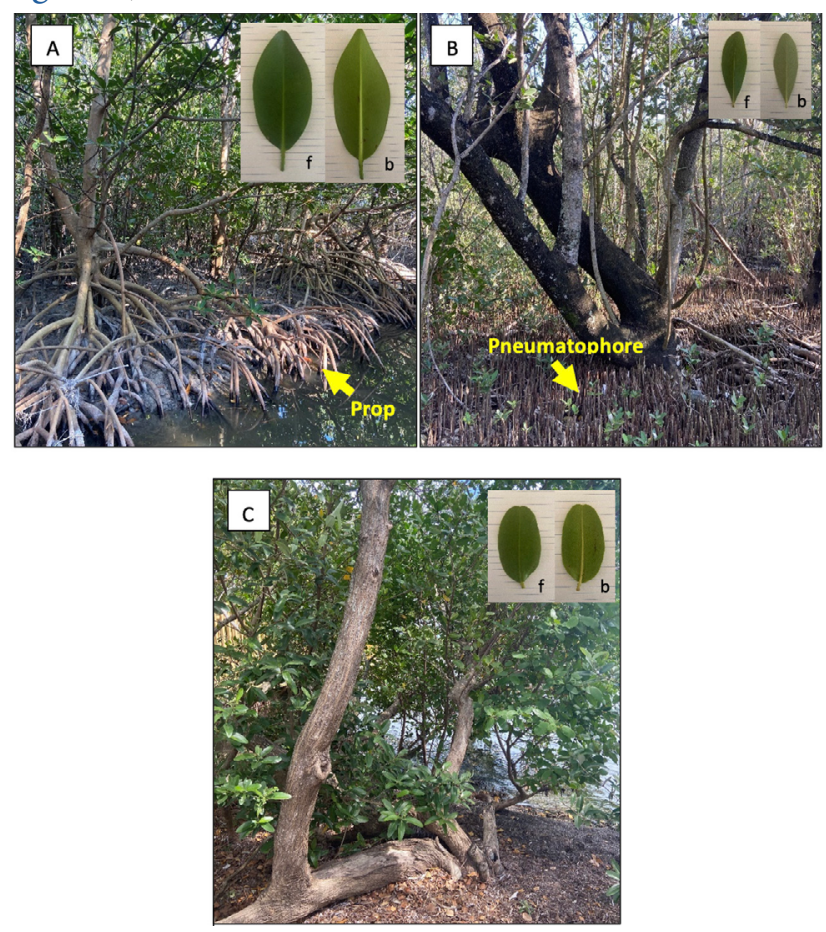

Figure 1. Images of the three native mangrove species found in Florida and the front $(f)$ and back $(b)$ of their leaves: $(A)$ the red mangrove (Rhizophora mangle), (B) the black mangrove (Avicennia germinans), and $(C)$ the white mangrove (Laguncularia racemosa).

Credits: G. Reyes, UF/IFAS

1. This document is SL493, one of a series of the Department of Soil and Water Sciences, UF/IFAS Extension. Original publication date January 2022. Visit the EDIS website at https://edis.ifas.ufl.edu for the currently supported version of this publication.

2. Gabriela Reyes, PhD student, Department of Soil and Water Sciences, UF/IFAS Tropical Research and Education Center; Ashley Smyth, assistant professor, Department of Soil and Water Sciences, UF/IFAS Tropical Research and Education Center; and Laura Reynolds, assistant professor, Department of Soil and Water Sciences; UF/IFAS Extension, Gainesville, FL 32611.

The Institute of Food and Agricultural Sciences (IFAS) is an Equal Opportunity Institution authorized to provide research, educational information and other services

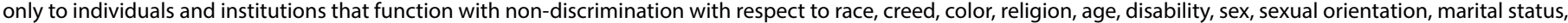

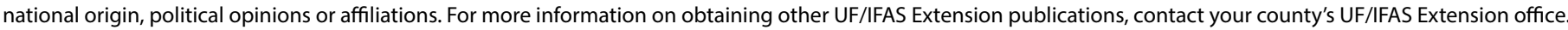
U.S. Department of Agriculture, UF/IFAS Extension Service, University of Florida, IFAS, Florida A \& M University Cooperative Extension Program, and Boards of County Commissioners Cooperating. Andra Johnson, dean for UF/IFAS Extension. 
Florida's mangroves are mostly found south of $28^{\circ} \mathrm{N}$ due to their sensitivity to freezing temperatures. However, with increasing temperatures caused by climate change, mangroves have started migrating northward and in recent years have persisted at latitudes up to $30^{\circ} \mathrm{N}$. The black mangrove is the most common species found at the northern limits in Florida because it is the most tolerant to cold temperatures. Red mangroves are also becoming common in the northern Gulf region.

Mangrove ecosystems are threatened by climate change and human activities. Over the last 50 years, $20 \%-35 \%$ of global mangrove extent has been lost (Polidoro et al. 2010). While mangrove loss has slowed in the 21 st century, $62 \%$ of the total global mangrove loss was attributed to human activities, such as drainage for agriculture and urban development between 2000-2016 (Goldberg et al. 2020). The decline in mangrove habitat area has consequences for shoreline stabilization, flood mitigation, and fisheries. The current and historical rate of mangrove loss is alarming considering their importance to wildlife and human society.

\section{What are urban mangroves?}

Urban mangroves are affected by cities and residential development. These mangroves can be found along park edges and in small patches near canals (Figure 2). While urban development often leads to mangrove loss, mangroves can still occur in tropical and subtropical coastal communities. Mangroves can exist in cities and residential areas because some coastal areas may have a gradual coastal slope needed for mangrove growth and survival. As salt-tolerant plants, mangroves can outcompete other vegetation that are not adapted to saline conditions. Urban mangroves may have naturally colonized post-development, been restored post-development, or be remnant from a larger mangrove forest pre-development.

Urban mangroves may look different than their pristine counterparts (Branoff 2017). For example, nitrogen concentrations in leaf and plant tissue of urban mangroves are high because of high nutrient concentrations found in urban stormwater. Under high-nutrient conditions, mangroves direct these nutrients to aboveground growth rather than to belowground root growth (Lovelock et al. 2009). As a result, urban mangroves may still grow to be large trees but may have fewer belowground roots than more pristine mangroves. Heavy metals, including copper, lead, and zinc, can be abundant in urban stormwater and are found in urban mangroves (Mills 1995; Branoff 2017). Urban mangroves serve as a heavy metal sink, but excess metals can decrease mangrove biomass and root growth
(MacFarlane and Burchett 2002). The chemical makeup of urban stormwater can have long-term effects on the way mangroves look.

In addition to urban stormwater, surrounding urban features, such as population density and percent urban infrastructure (e.g., roads and buildings), may affect the size (i.e., hectares) of a mangrove patch. Mangroves have historically been removed in Florida to make way for coastal urban development, which fragments, or minimizes, mangrove forest area (US Fish and Wildlife Service 1999). There is also limited space for mangroves to expand along the coasts of cities because of concrete structures. On the seaward side, sea level continues to rise, which forces mangroves to migrate landward. However, urban development serves as a barrier that prevents mangroves from moving inland. The combination of urban development on one side and sea-level rise on the other results in a "coastal squeeze," further minimizing space for mangrove growth. For these reasons, most urban mangroves may be small patches, as opposed to the large forests that are typically found in conserved areas, such as the Everglades National Park.
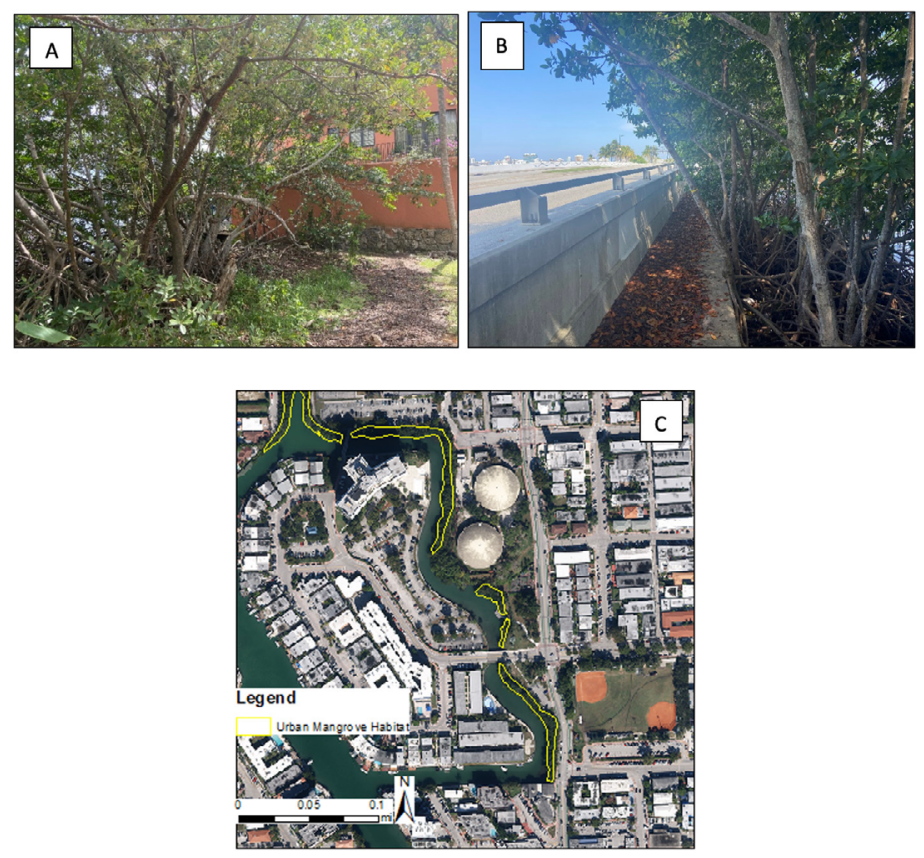

Figure 2. Images of urban mangroves in Miami-Dade County, FL: (A) mixed red, black, and white mangrove stand next to a housing complex, (B) red mangroves next to a major road, and (C) an aerial image of urban mangroves located near Normandy Isles in Miami Beach, FL.

Credits: G. Reyes, UF/IFAS; Aerial image from Miami-Dade County 


\section{What ecosystem services do urban mangroves provide?}

Urban mangroves are important for providing ecosystem services, or benefits to humans, such as carbon sequestration, nutrient removal, nursery habitat for fish, wave attenuation, and flood mitigation. These ecosystem services are especially beneficial to coastal communities in need of coastal protection in the face of sea-level rise and climate change. Coastal vegetation has historically been replaced by concrete structures, such as bulkheads and seawalls, to protect property from storm surges. However, these concrete structures can fail over time. Mangroves are dynamic ecosystems that can continue to grow and outpace sea-level rise, possibly serving as a better alternative for protecting cities from storm surges and coastal erosion (Currin 2019).

Mangroves in urban areas are also essential habitat for urban wildlife because green spaces can be few and far between in cities. Increased wildlife provides recreational and commercial ecosystem services. Valuable commercial fish species, including flathead grey mullet, sheepshead, blue crab, and penaeid shrimp, can still be abundant in urban mangroves, as demonstrated in a study conducted in Tampa, Florida (Krebs et al. 2014). Up to $90 \%$ of commercial fishery species and $70 \%$ of sport fishery species depend on mangroves at some point in their life cycles (US Fish and Wildlife Service 1999). Urban mangroves are also important habitat for birds that rely on these ecosystems for nesting. While possibly smaller in size, urban mangrove patches can still support coastal wildlife and remove nutrients and other containments.

With increasing climate changes, south Florida's growing cities may depend on the restoration and conservation of urban mangrove ecosystem services for sustaining the livelihoods of city dwellers. The University of Florida's Bureau of Economic and Business Research calculated a $14.9 \%$ population increase in Florida between 2010 and 2020 (Bureau of Business and Economic Research 2020). Mangroves also provide nursery habitat for many fish (Lefcheck et al. 2019). Urban mangroves are also important habitats because of their ability to store and filter contaminants from the urban stormwater before entering coastal waters. Given their proximity to human populations, urban mangroves may provide more direct ecosystem services to humans than their pristine counterparts, which tend to be in secluded areas. Because of their importance to humans and properties, mangrove restoration is becoming recognized by scientists and land developers as a tool for returning ecosystem services to urban communities (Worthington and Spalding 2018; Erwin 2009).

\section{Conclusions}

Mangroves exist in heavily urbanized areas. Urban mangroves face unique challenges because of their location, such as habitat fragmentation as well as high nutrient and metal concentrations. Given their proximity to cities, urban mangroves may be providing direct ecosystem services to more people. Even the restoration of small mangrove areas may provide ecosystem services to large groups of people. These ecosystem services are key for protecting coastal cities from the effects of climate change, including storm surges and flooding from hurricanes. Urban mangrove conservation and restoration can serve to maintain important services as human populations and climatic changes continue to increase and cities continue to expand.

\section{References}

Branoff, B. L. 2017. "Quantifying the Influence of Urban Land Use on Mangrove Biology and Ecology: A Meta-analysis." Global Ecology and Biogeography 26 (11): 1339-1356. https://doi.org/10.1111/geb.12638

Bureau of Business and Economic Research. 2020. "Population Studies Program.” https://www.bebr.ufl.edu/population

Currin, C. A. 2019. "Living Shorelines for Coastal Resilience." In Coastal Wetlands, Second Edition, edited by G. M. E. Perillo, E. Wolanski, D. R. Cahoon, and C. S. Hopkinson, 1023-1053. Elsevier. https://doi.org/10.1016/ B978-0-444-63893-9.00030-7

Duke, N., I. Nagelkerken, T. Agardy, S. Wells, and H. van Lavieren. 2014. The Importance of Mangroves to People: A Call to Action. Edited by J. van Bochove, E. Sullivan, and T. Nakamura. Cambridge: United Nations Environment Programme World Conservation Monitoring Centre.

Erwin, K. L. 2009. "Wetlands and Global Climate Change: The Role of Wetland Restoration in a Changing World." Wetlands Ecology and Management 17 (1): 71-84. https:// doi.org/10.1007/s11273-008-9119-1

Goldberg, L., D. Lagomasino, N. Thomas, and T. Fatoyinbo. 2020. "Global Declines in Human-Driven Mangrove Loss." Global Change Biology 26 (10): 5844-5855. https://doi. org/10.1111/gcb.15275 
Krebs, J. M., S. S. Bell, and C. C. McIvor. 2014. "Assessing the Link between Coastal Urbanization and the Quality of Nekton Habitat in Mangrove Tidal Tributaries."

Estuaries and Coasts 37:832-846. https://doi.org/10.1007/ s12237-013-9724-y

Lefcheck, J. S., B. B. Hughes, A. J. Johnson, B. W. Pfirrmann, D. B. Rasher, A. R. Smyth, B. L. Williams, M. W. Beck, and R. J. Orth. 2019. "Are Coastal Habitats Important Nurseries? A Meta-analysis." Conservation Letters 12 (4): e12645. https://doi.org/10.1111/conl.12645

MacFarlane, G. R., and M. D. Burchett. 2002. "Toxicity, Growth and Accumulation Relationships of Copper, Lead and Zinc in the Grey Mangrove Avicennia marina (Forsk.) Vierh." Marine Environmental Research 54 (1): 65-84. https://doi.org/10.1016/S0141-1136(02)00095-8

Narayan, S., M. W. Beck, B. G. Reguero, I. J. Losafa, B. van Wesenbeeck, N. Pontee, J. N. Sanchirico, J. C. Ingram, G.-M. Lange, and K. A. Burks-Cope. 2016. "The Effectiveness, Costs and Coastal Protection Benefits of Natural and Nature-Based Defences." PLoS ONE 11 (5): e0154735. https://doi.org/10.1371/journal.pone.0154735

Pickett, S. T. A., M. L. Cadenasso, J. M. Grove, C. H. Nilon, R. V. Pouyat, W. C. Zipperer, and R. Costanza. 2001. "Urban Ecological Systems: Linking Terrestrial Ecological, Physical, and Socioeconomic Components of Metropolitan Areas." Annual Review of Ecology and Systematics 32:127-157. https://doi.org/10.1146/annurev.ecolsys.32.081501.114012

Polidoro, B. A., K. E. Carpenter, L. Collins, N. C. Duke, A. M. Ellison, J. C. Ellison, E. J. Farnsworth, E. S. Fernando, K. Kathiresan, N. E. Koedam, S. R. Livingstone, T. Miyagi, G. E. Moore, V. Ngoc Nam, J. E. Ong, J. H. Primavera, S. G. Salmo, J. C. Sanciangco, S. Sukardjo, Y. Wang, and J. W. H. Yong. 2010. "The Loss of Species: Mangrove Extinction Risk and Geographic Areas of Global Concern." PLoS ONE 5 (4): e10095. https://doi.org/10.1371/journal.pone.0010095

US Fish and Wildlife Service Southeast Region. (1999). South Florida Multi-Species Recovery Plan - Ecological Communities: Mangroves [White paper]. https://www.nrc. gov/docs/ML1219/ML12193A340.pdf

Worthington, T., and M. Spalding. 2018. Mangrove Restoration Potential: A Global Map Highlighting a Critical Opportunity. The Nature Conservancy Report. https://doi. org/10.17863/CAM.39153 